\title{
Empirical Research of Chinese Residents' Consumption Behaviors Based on Consumption Functions
}

\author{
Yan Xiao, Liting Liao \\ Economic Department, Central South of Forestry and Technology, Changsha, China \\ Email: xiaoyan3829@163.com
}

How to cite this paper: Xiao, Y. and Liao, L.T. (2018) Empirical Research of Chinese Residents' Consumption Behaviors Based on Consumption Functions. American Journal of Industrial and Business Management, 8, 1517-1535.

https://doi.org/10.4236/ajibm.2018.86102

Received: May 17, 2018

Accepted: June 12, 2018

Published: June 15, 2018

Copyright $\odot 2018$ by authors and Scientific Research Publishing Inc. This work is licensed under the Creative Commons Attribution International License (CC BY 4.0).

http://creativecommons.org/licenses/by/4.0/

\begin{abstract}
This paper simply expands two famous consume functions referring to macro-economics: Keynesian consumption function and Life-cycle consumption function; attempting to introduce the empirical proxy variance of irrational facts: money illusion and over-reaction, we rebuild a new Keynesian consumption model and Life-cycle consumption model, both of which are based on the hypothesis of resident's irrational behavior. Then we use the new model to empirically test the macroeconomic years' data of China's urban residents from 1978 to 2013 and China's rural residents from 1985 to 2013. The empirical results show that all residents of China are irrational, however, the reasons of cause irrational consumption are different, and the urban residents may be for money illusion, but the rural residents may show over-reaction to price volatility. Finally, we give theory analysis about the differences of the two irrational consumption behaviors and the results of the paper.
\end{abstract}

\section{Keywords}

Money Illusion, Over-Reaction, Irrational Consumption Behavior

\section{Introduction}

The theoretical research on consumption functions is a significant project. Certainly, it is of greatly challenging and innovative. Both of prominent Economists (Keynes and Friedman) in $20^{\text {th }}$ century are well known for their researches on consumption functions. Therefore, it can be deemed without fear of exaggeration that consumption function theory is one of the most important foundations of macroeconomics. Keynes proposed the Keynesian consumption function firstly in his macroeconomics masterpiece, The General Theory of Employment, 
Interest, and Money, and established Keynes' Macroeconomics Theory. There are three assumptions in the Keynesian consumption function: the first one is that the level of consumption is determined by the level of income (consumption levels are shown in Figure 1 and Figure 2), and the interest rate plays a secondary role; the second one is that the average propensity to consume will decrease as income increases; the last one is that the marginal consuming tendency is between 0 and 1. It is experimentally successful for the Keynesian consumption function in the early empirical studies, however, after the early 1940's, the well-known economist Kuznets found the famous consumption mystery: the average propensity definitely decreases as income increases in a short time, however, it will gradually tend to be stable in a long time. To explain the consumption mystery, the celebrated economist Friedman established the permanent income hypothesis consumption function during 1950's, which was based on Fisher's researches on consumer behavior, while another well-known economist Modigliani developed the model for lifecycle consumption. The Rational Expectations School represented by Lucas, prevailed in 1970's. His follower, Robert Hall, proposed a consumption function based on the rational expectation theory-the random walk consumption function. After entering $21^{\text {st }}$ century, theoretical researches on consumption functions mainly focus on the theory of precautionary saving and liquidity constraint hypothesis.

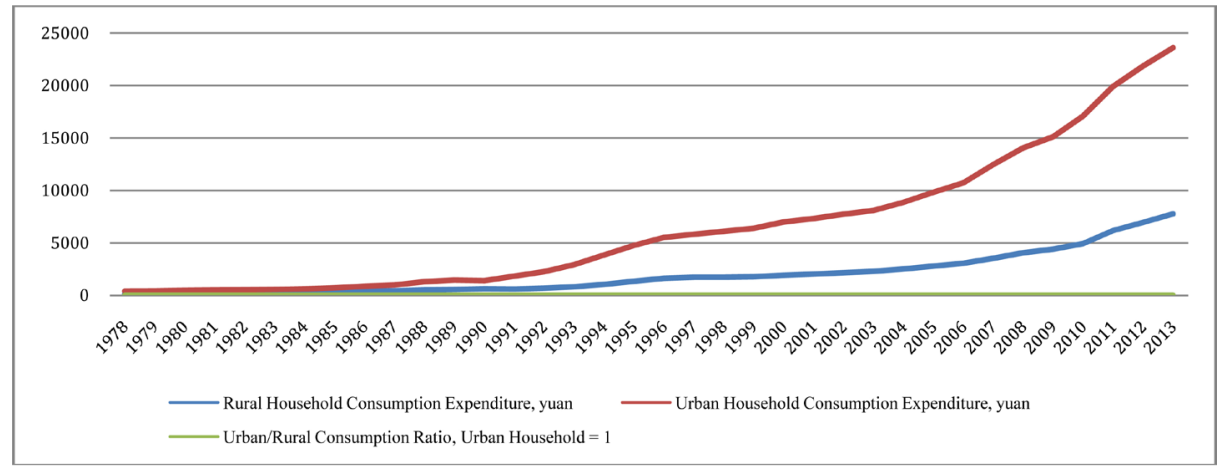

Figure 1. Rural and urban household consumption expenditure, yuan. Data source: NBS, Collected by EPS DATA.

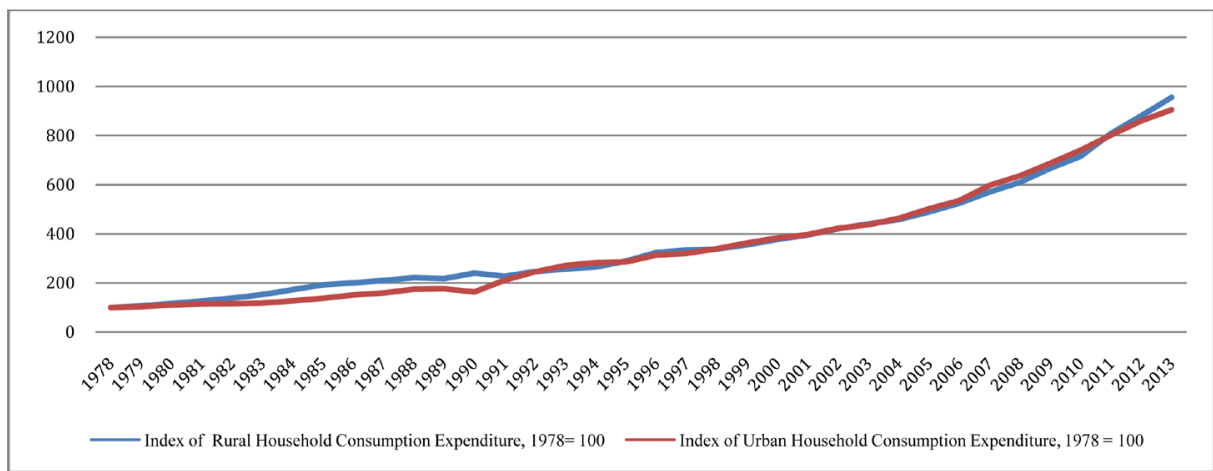

Figure 2. Index of rural and urban household consumption expenditure, $1978=100$. Data source: NBS, Collected by EPS DATA. 
Keynes considers the assumption function as the basic rhythm, and studies this function from the view of psychology. However, following researches on assumption functions suppose consumers are the rational economic man who pursues utility maximization, and these functions prefer establishing optimal model to studying consumers' own behavior. Therefore, consumers' real decision-making clashes with the static consumption model which is based on the hypothesis of rational man, which leads to poor simulation of real economy. The real world is always changing; custom and human nature vary in different regions; the consuming concept differs between generations; and it is hard to collect and discriminate this information; so irrational factors, such as herding behavior, flaunting wealth, carpe diem, monetary illusion, overreaction and etc. will arise and impact people's consumption decision finally. This paper is based the view of behavioral economics, and considers how the Keynesian and the lifecycle consumption functions behave and how to modify these functions under the assumption that consumers have the monetary illusion and overreaction. And based on these researches, this paper makes post hoc inspection to the historical consumption level of Chinese residents. The result shows consumption behavior of Chinese residents is irrational. Further researches manifest irrational consumption behavior of Chinese residents in urban areas and the one in rural areas differs: urban residents have more irrational consumption behavior, for their being affected by the monetary illusion, while rural residents are more likely affected by overreaction to the fluctuation of commodity prices. This conclusion will be of great of realistic significance to promoting consumption, pulling growth in China's present economic development.

\section{Research Method}

\subsection{A Review of Irrational Consumer Behavior}

Irrational consumer behavior refers to the subjective or objective lack of reasonable basis for consumers to buy, use or accept services directly or indirectly, based on the needs of living consumption, and thus produce negative social impact. There is an attractive simplicity to the notion that consumers choose what they most prefer, that they are logical decision-makers with abundant time and complete insight into the factors determining the choices they make. The well-documented emergence of behavioral economics (BE) has dramatically deepened and broadened our understanding of consumer decision making. Many marketers, for example, are familiar with "nudges" - small changes in how options are presented that influence consumers' choices.

Nowadays, domestic or abroad researches about irrational consumption behavior mainly focus on the four following aspects: the explanation of the appearance of irrational consumption behavior: Yonggang Wei and Xiaoling Su (2005) [1] used consumers' psychological account to explain the reasons; Wei Luo and $\mathrm{Xu}$ Wan (2010) [2] summarized the reasons of irrational consumption behavior. Secondly, the empirical research of irrational consumer behavior: Jia- 
gang Liu and Leshan Liu (2006) [3] did empirical research on three irrational behaviors: cautious consumption, depletion consumption and abnormal consumption, and found out that Chinese consumption behaviors are basically coincide with these three theories; they did further research and found out: diligent and thrifty consumers pay more attention to saving, consumers vain enough pay more attention to consume, irrational consumption behaviors have great influence on Chinese market. Thirdly, the discussion on submarket irrational consumption behavior, Zhi Ren (2011) [4] did some research on specific appearance of irrational consumption behavior in insurance market, and provide several solutions to this behavior: Wei Du (2014) [5] has analyzed the special features, influence factors and ways of reduction of irrational consumption behavior. Zhiling Fang (2015) [6] thought Chinese residents' irrational consumption behaviors are getting worse in post financial crisis era, and provide causes and solutions toward this problem. Fourthly, microscopic analysis among irrational consumption behaviors on sub-population: Xiumei $\mathrm{Ru}$ (2010) [7] thought that the irrational consumption behaviors of peasant is getting worse, this may cause negative influence on new rural construction; Zhi Yin (2014) [8] did some research on college students in University of South China, and analyzed the potential influence of irrational consumption, and provide some specific measures.

\subsection{A Review of Money Illusion}

Money illusion is a vision of irrational behavior that people only consider the nominal value instead of the actual value of currency while they are making decisions. The study of money illusion can generally be divided into three aspects: First of all, the theoretical study of money illusion. Fisher (1928) [9] and Patinkin (1965) [10] gave different definition to money illusion from different views; Shafir, Diamond and Tversky (1997) [11] studied the existence of money illusion in real-life trade, contract-making and some other respects, and explained money illusion through framing effects and psychological account; Tobin (1972) [12] and Akerlof (2002) [13] held two opposite attitudes towards money illusion, that Tobin (1972) strongly opposed money illusion, he though it can lead to irremissible mistakes, but Akerlof (2002) thought it should be included in macro-economic study. Secondly, the measurements study of money illusion. Modigliani (1979) [14] came up with money illusion hypothesis in capital market; Campbell (2004) [15] identified the US's error estimate in stock market can be explained by money illusion by setting Linear Gordon model and vector auto regression estimate skills; Brunnermeier and Christian Julliard (2008) [16] affirmed UK's irrational mania in property market was caused by money illusion by setting Log linear dynamic price rent ratio model and vector auto regression estimate skills; Cohen Polk (2005) [17], Renhe Liu (2009) [18], Guojin Chen (2009) [19], Zongxin Zhang and Weihua Zhu (2010) [20] and so on used Campell's (2004) model and methods as reference, did some money illusion tests in 
property market and stock market in different areas and times. Thirdly, experimental research of money illusion, Fehr Tyran (2007) [21] is the best in this field. Fehr Tyran used equilibrium strategy game model of experimental economics, and did some systemic and deep research to the phenomenon of money illusion; Bakshi's (2009) [22] did some experiment to those university students who accept economic education, he found out that people can still be effected by money illusion even they got strict economic training.

\subsection{A Review of Overreaction}

Overreaction was brought up by De Bondt and Thaler (1985) [23] for the first time, and has been mostly applying in empirical test on stock market. Many foreign economists had empirical studies on overreaction in stock market, representative literature include: Fama (1981) [24] etc. There are lots of works about overreaction in China as well, they can specifically be divided into following three types: first of all is empirical works about overreaction in stock market, which are the most common type, representative literature are Renji Zhang (1998) [25], Lei Wang (2011) [26], Guihua Lu (2012) [27], Hongxia Gao (2015) [28] etc. These papers got some general problems like having small size in empirical samples, lack of stability in conclusions. The second type is studies on overreaction in future market, there isn't much works in this type, Shu Jiang (2007) [29] tested the validity of China's future market by utilizing overreaction. Xiaopeng Zou (2003) [30], Luojia Cai (2006) [31] and so on have done some similar research. The third types are studies on overreaction behaviors in macro-economic market, the most typical literature is Gang Gong and Yifu Lin (2007) [32] used a discrete dynamic model to study the phenomenon of economic growth and deflation in business cycle, and they discovered that when there is a stable high growth of economic, an excessive investment can make deflation and economic growth become possible at the same time.

\section{Empirical Model Construction}

\subsection{Irrational Keynesian Consumption Function Model Construction}

In the "The General Theory of Employment, Interest, and Money", Keynesian put forward an idea that people's consumption level rest with income level, therefore, Keynesian consumption function is defined as:

$$
C=\alpha+\beta Y+\varepsilon
$$

In Equation (1), $C$ represents residents' total consumption level, $Y$ represents residents' total income, $\alpha$ represents essential consumption expenditure, and $\alpha>$ $0, \beta$ represents marginal propensity to consume and $0<\beta<1$. Keynesian consumption function is based on general level, if it divided by resident total population respectively and removes price element. We can get Keynesian actual consumption function per capita: 


$$
\frac{C}{N P}=\alpha+\beta \frac{Y}{N P}+\varepsilon
$$

In Equation (2), $N$ represents total population, $P$ represents price level. Suppose $c=C / N P$ represents residents' actual consumption per capita, and $y=Y / N P$ represents residents' actual income per capita, Keynesian actual consumption per capita would become:

$$
c_{t}=\alpha+\beta y_{t}+\varepsilon_{t}
$$

For rational consumers, they can distinguish from nominal income, nominal consumption and price level momentarily, thus, price volatility can't affect strategies of actual consumption expenditure for rational agents, conversely. If consumers are irrational or limited rationality, actual consumption strategies must be influenced by agents. So in order to construct irrational Keynesian consumption function, price level is only an individual variance, which lead into Equation (3), so we can get irrational Keynesian consumption function:

$$
c_{t}=\alpha+\beta y_{t}+\gamma P_{t}+\varepsilon_{t}
$$

We can propose three suppositions from Equation (4)

Supposition H1a: suppose $\gamma>0$, and is evident statistically, which shows that consumers are irrational because of money illusion. Because when the price level and the nominal income ascend at the same rate, although consumer' real purchasing power has no change, consumers who are influenced by the monetary illusion tend to only care about their nominal income. While, they neglect the inflation of the whole price level in society, which results in making the irrational decision to increase their real consumption.

Supposition $\mathrm{H} 1 \mathrm{~b}$ : suppose consumers are rational absolutely, so $\gamma=0$. If consumers are completely rational, the price expectancy can be adjusted at any time. When expecting rise of the future price, rational consumers will transfer future consumptive level to current level. Price expectancy mechanism just plays a role in resources allocation during the whole rational consumption decision; Therefore the rise and fall of prices will not affect per capita real consumption level.

Supposition H1c: suppose $\gamma<0$, and is obvious statistically, which shows that consumers are irrational, owing to over-reaction to price volatility. Because when the price fluctuation becomes unsteady, the uncertainty of future economy will increase. At that time, consumers especially the consumers from bottom of the society always are easily influenced. As a result, they will show excessive pessimistic emotions and exaggerate the bad news of inflation subjectively, which leads them to cutting down current consumption. The result of their behavior is leading to inflation and lowering the real per capita consumption level.

\subsection{Irrational Life-Cycle Consumption Function Model Construction}

The original intention that Modigliani built the life cycle consumption function 
is assuming that consumer spend the whole income of his entire life steadily, assuming that the overall wealth of consumption is $W$. His lifetime is $N$ years, his working time of the whole life is $n$. Income per year is $Y$. According to Modiglia$\mathrm{ni}$, consumers' average consumption level per year $C$ is:

$$
C=(W+n Y) / N=(1 / N) W+(n / N) Y
$$

Facilitating Equation (5), the initial form of Life-cycle consumption function is:

$$
C=\alpha+\beta W+\gamma Y+\varepsilon
$$

From Equation (6), $\beta$ is wealth of marginal propensity to consume; $\gamma$ is income of marginal propensity to consume total wealth and disposable personal income divided by national total population, in the precondition of reducing price level, hence we can get Life-cycle actual consumption function per capita:

$$
\frac{C}{N P}=\alpha+\beta \frac{W}{N P}+\gamma \frac{Y}{N P}+\varepsilon
$$

In Equation (7), $C$ is total consumption. $W$ is total wealth. $Y$ is total income. $N$ is residents' total population. $P$ is price level. $c=C / N P$ represents resident actual consumption level per capita. $w=W / N P$ represents resident actual wealth level, $y=Y / N P$ represents resident income per person. So equation (7) can be changed as:

$$
c_{t}=\alpha+\beta w_{t}+\gamma y_{t}+\varepsilon_{t}
$$

Similarly, suppose consumers are irrational, price level could make an independent difference on actual consumption level per capita, thus irrational Life-cycle consumption function can use format as follows:

$$
c_{t}=\alpha+\beta w_{t}+\gamma y_{t}+\delta P_{t}+\varepsilon_{t}
$$

In the view of empirical examination, data of real wealth per capita is hard to estimate. As a matter of fact, lots of nations (including China), official statistical data of residents wealth is missing. Therefore, we deduce residents wealth level with the help of mathematical logic, so real wealth level per capita can be described as:

$$
w_{t}=w_{t-1}+\left(y_{t-1}-c_{t-1}\right)
$$

In Equation (10), $w_{t-1}$ represents residents' actual net wealth level per capita in phase $t-1 . \quad y_{t-1}$ represents residents' disposable income per capita in phase $t-1 . \quad c_{t-1}$ represents residents' actual consumption level per capita. Equation (9) can be written in the form of first-order lag as follow:

$$
c_{t-1}=\alpha+\beta w_{t-1}+\gamma y_{t-1}+\delta P_{t-1}+\varepsilon_{t-1}
$$

Residents' actual net wealth level per capita $w_{t-1}$ in phase $t-1$ can be deducted from Equation (11) as below:

$$
w_{t-1}=\frac{1}{\beta} c_{t-1}-\frac{1}{\beta}\left(\alpha+\gamma y_{t-1}+\delta P_{t-1}+\varepsilon_{t-1}\right)
$$


Put Equation (12) into Equation (10), then:

$$
w_{t}=-\left(\frac{1}{\beta}\right) \alpha+\left(\frac{1}{\beta}-1\right) c_{t-1}+\left(1-\frac{\gamma}{\beta}\right) y_{t-1}-\left(\frac{\delta}{\beta}\right) P_{t-1}-\left(\frac{1}{\beta}\right) \varepsilon_{t-1}
$$

Next, put Equation (13) into Equation (9), then:

$$
c_{t}=(1-\beta) c_{t-1}+(\beta-\gamma) y_{t-1}+\delta\left(P_{t}-P_{t-1}\right)+\gamma y_{t}+\left(\varepsilon_{t}-\varepsilon_{t-1}\right)
$$

As a result, the general model of irrational Life-cycle consumption function can be defined as:

$$
c_{t}=\alpha c_{t-1}+\gamma y_{t}+(1-\alpha-\gamma) y_{t-1}+\delta \Delta P_{t}+\mu_{t}
$$

In Equation (15), $c_{t}$ represents the actual consumption per capita in phase $t$, $c_{t-1}$ represents the actual consumption per capita in phase $t-1 . \Delta P_{t}$ is the gap of price level between phase $t-1$ and phase $t . y_{t}$ represents the real income level per capita in phase $t . y_{t-1}$ represents the real income level per capita in phase $t-1$. From Equation (15), three hypotheses can be made as following:

Hypothesis H2a: suppose $\delta>0$, and is evident statistically, then consumers are irrational and are influenced by money illusion effect.

Hypothesis H2b: suppose consumers are perfectly rational, then $\delta=0$.

Hypothesis H2c: suppose $\delta<0$, and is evident statistically, then consumers' consumption behaviors are irrational, and consumers are over-reacted to the price volatility.

The Equation (15) is a datum equation of irrational Life-cycle consumption function, an autoregressive model with lagged first order. There are three parameters, and the Generalized Method of Moments (GMM) needs to be applied to estimate parameters in order to avoid the over recognition of the model and the heteroscedasticity, serial correlation and other related problems during the estimating process.

\section{Results and Analysis of Empirical Test}

\subsection{Sources of Data and Data Processing}

After establishing Keynesian irrational consumption function and life cycle consumption function, the macro economic data of Chinese residents are applied to the two models using OLS and GMM fitting to test whether the consumption behavior of Chinese consumers are influence by irrational factors, such as money illusion and overreaction as expected.

The statistics used for empirical study in this article are from China Statistics Yearbook of 2014, the sample periods are: annual statistics of Chinese city dwellers from 1978 to 2013, and the annual statistics of Chinese rural residents from 1985 to 2013. (Since China's rural consumer price index (CPI) was only compiled in 1985, the empirical sample period was 1985-2013.)

The detailed descriptions about the data processing are as following and the specific data is shown in Table 1.

First, gather the Fixed Base Price Index in China Urban and Rural Residents is directly from China Statistics Yearbook of 2014; 
Table 1. Descriptive statistics of real income, consumption and fixed price index of urban and rural residents in China.

\begin{tabular}{ccccccc}
\hline & \multicolumn{3}{c}{ Urban residents: 1978-2015 } & \multicolumn{3}{c}{ Rural residents: 1985-2015 } \\
\hline & $\begin{array}{c}\text { Per capita real } \\
\text { consumption } \\
\text { level }\end{array}$ & $\begin{array}{c}\text { Per capita } \\
\text { disposable } \\
\text { income }\end{array}$ & $\begin{array}{c}\text { Fixed base } \\
\text { consumer } \\
\text { price index }\end{array}$ & $\begin{array}{c}\text { Per capita real } \\
\text { consumption } \\
\text { level }\end{array}$ & $\begin{array}{c}\text { Per capita } \\
\text { disposable } \\
\text { income }\end{array}$ & $\begin{array}{c}\text { Fixed base } \\
\text { consumer } \\
\text { price index }\end{array}$ \\
\hline $\begin{array}{c}\text { Sample size } \\
\text { Mean value }\end{array}$ & 1598.92 & 2147.03 & 277.52 & 763.27 & 919.96 & 297.08 \\
$\begin{array}{c}\text { Maximum } \\
\text { value }\end{array}$ & 4345.76 & 6337.22 & 492.25 & 1989.86 & 2464.29 & 463.50 \\
$\begin{array}{c}\text { Minimum } \\
\text { value }\end{array}$ & 417.36 & 460.84 & 74.52 & 339.19 & 380.94 & 100.00 \\
$\begin{array}{c}\text { Standard } \\
\text { deviation }\end{array}$ & 1129.05 & 1725.98 & 144.23 & 469.83 & 575.81 & 111.40 \\
Skewness & 1.01 & 1.08 & -0.17 & 1.25 & 1.19 & -0.35 \\
Kurtosis & 2.84 & 2.92 & 1.50 & 3.49 & 3.44 & 2.00 \\
JB value & 6.52 & 7.41 & 3.73 & 8.35 & 7.60 & 1.93 \\
\hline
\end{tabular}

Data source: China Statistical Yearbook from 1978-2013.

Second, gather the real consumption expenditure of Chinese residents per capita, and remove the effects of price levels, then the function become:

$$
c_{t}=\left(\frac{100}{P_{t}}\right) \times\left(\frac{C_{t}}{N_{t}}\right)
$$

$C_{t} / N_{t}$ stands for the consumption expenditure per capita; $P_{t}$ stands for the fixed base price index.

Third, gather data of Chinese urban residents' real disposable income per capita or rural residents' net income per capita from China Statistics Yearbook of 2014, and the computational formula is:

$$
y_{t}=\left(\frac{100}{P_{t}}\right) \times\left(\frac{Y_{t}}{N_{t}}\right)
$$

$Y_{t} / N_{t}$ stands for the urban residents' real disposable income per capita or the rural residents' net income per capita, $P_{t}$ stands for the fixed base price index.

\subsection{Statistics Description}

Figure 3 shows Chinese residents' annual nominal income, consumption and their ratio from 1978 to 2003 . Conclusions can be drawn that: the consumption and income level of Chinese residents is improving annually. In 2013, the real disposable income per capita of Chinese residents has increased almost 78 times compared to 1978. The net income of rural residents per capita has increased by almost 66 times compared to that of 1978; the consumption level of Chinese city residents increases by almost 56 times compared to that of 1978; and the consumption level of rural residents has increased by 53 times. 

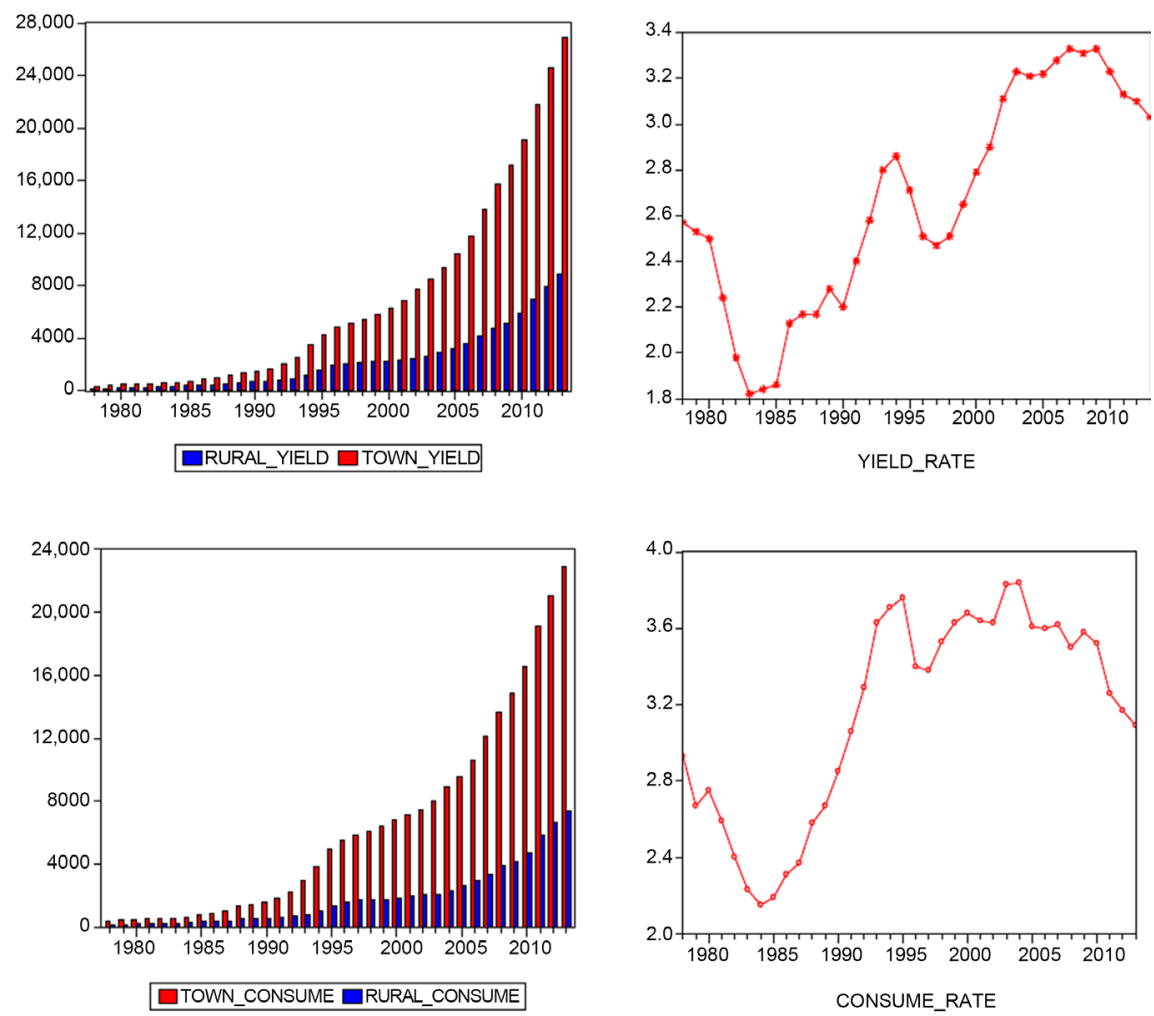

Figure 3. Chinese residents' nominal income, nominal consumption and their ratio (1978-2013). Data source: China Statistical Yearbook from 1978-2013.

The speed of increase has shown a high relevant tendency, rising first, then going down and then increasing again, which shows that the consumption level is mainly depend on income level. Besides, the consumption difference between rural and city residents is quite obvious. Even when the economy is in depression, the consumption level of city residents was 2 times higher than that of urban residents. Although in the early years of the Reform and Opening-up and in recent years, the level of income and consumption between Chinese rural and city residents showed a decline tendency, the main trend of them is becoming larger.

Figure 4 is the time series graph of Empirical data in irrational Keynesian model and life cycle model, those statistics include: real disposable income of Chinese urban residents per capita, real consumption level of Chinese urban residents per capita and Chinese rural residents' fixed base consumer price index from 1978 to 2013; Chinese rural residents' real net income, real consumption level, and their fixed base consumption price index from 1985 to 2013.

\subsection{Analysis of Empirical Test Results}

Table 2 shows the estimated results of Keynesian irrational consumption of Chinese urban and rural residents. The picture on the left is the OLS regression of Chinese urban residents' actual consumption level per capita of the per capita disposable income and fixed base consumer index of urban areas. The picture on 
Table 2. Irrational Keynesian estimate function of Chinese residents.

\begin{tabular}{ccccccccc}
\hline $\begin{array}{c}\text { The estimate results of the irrational Keynesian } \\
\text { function of China's urban residents }\end{array}$ & \multicolumn{4}{c}{$\begin{array}{c}\text { The estimate results of the irrational Keynesian } \\
\text { function of China's rural residents }\end{array}$} \\
\hline C & Real_Yield & CPI & $R^{2}$ & C & Real_Yield & CPI & $R^{2}$ \\
\hline $60.58^{* * *}$ & $0.69^{* * *}$ & $0.87^{* * *}$ & & $44.15^{* * *}$ & $0.86^{* * *}$ & $-0.24^{* * *}$ & \\
{$[12.15]$} & {$[0.009]$} & {$[0.056]$} & $\begin{array}{c}99.8 \\
(\%)\end{array}$ & {$[9.74]$} & {$[0.014]$} & {$[0.061]$} & 99.8 \\
$(4.99)$ & $(73.42)$ & $(15.61)$ & & $(4.53)$ & $(60.66)$ & $(-3.92)$ & \\
\hline
\end{tabular}

Note: ${ }^{* * *}$ represents the statistical significance level of $1 \%$, [] is the standard error, and () is the t-statistic value. Data source: China Statistical Yearbook.
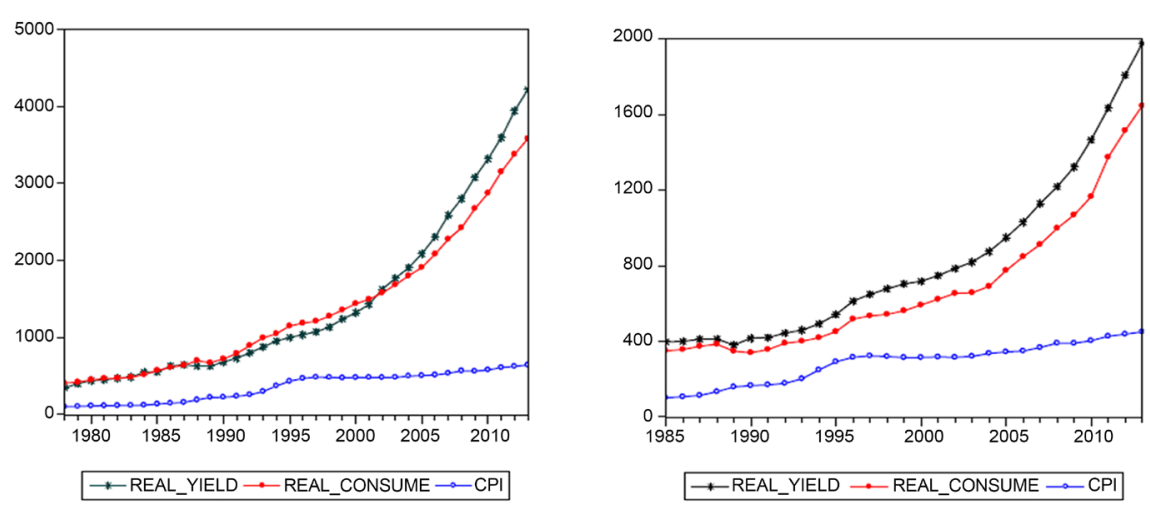

Figure 4. Chinese rural residents' real income, consumption and CPI. Data source: China Statistical Yearbook.

the right is the OLS regression of per capita actual consumption level of China's rural residents' of the per capita net income of rural residents and fixed base consumer price index of rural residents. According to the results of regression in Table 2, three conclusions can be drawn:

First, the consumption behaviors of Chinese urban and rural residents are irrational. Because the price fluctuation of residents' real consumption and income has been removed, the real consumption level is only influenced by real income level and is unrelated to the price fluctuation. However, according to the regression results, the regression coefficient of Chinese urban and rural residents' real consumption level and price of being $1 \%$ reject the null hypothesis of being zero. This has shown that there is an obvious relevance between them.

Second, even though all the Chinese residents are irrational, the reasons of their irrationality are different. Urban resident tend to be influenced mainly by money illusion, while rural residents tend to be mainly influenced by over-reaction to the price volatility. The empirical results suggest that the regression coefficient between the Chinese urban residents real income per capita and the price level of is 0.87 , which matches the expectation of money illusion hypothesis mentioned previously. The regression coefficient between Chinese rural residents real income per capita and the price level is -0.24 , which matches the over-reaction hypothesis. 
Third, it is necessary to make some adjustment of the current Keynesian consumption function of Chinese residents to take some irrational factors into account. According to the regression results, including price factors has enhanced the estimation effect, the regression result has increased statistically, and the irrational Keynesian estimate function of Chinese urban residents can be shown as: Real_Consume $=60.58+0.69 \times$ Real_Yield $+0.87 \times$ CPI, and the irrational Keynesian estimate function of Chinese rural residents can be shown as: Real_Consume $=44.15+0.86 \times$ Real_Yield $-0.24 \times$ CPI .

Table 3 shows the estimation result of Chinese residents' irrational life-cycle consumption. There are only 3 parameters needed to be estimated in Equation (15), while four explaining variables are used. Thus, GMM should be used to avoid the over recognition problems of the model. There are three conclusions that can be drawn according to Table 3 .

First, the consumption behaviors of Chinese residents are irrational. Because the regression result shows again: the regression coefficient between China's rural and urban residents' actual consumption level and increment of price both refuse to the original assumption which got 0 regression coefficient at the $1 \%$ statistic significance level, which shows an obvious correlation between them;

Second, it proves again that although all the consumption behaviors of Chinese residents are irrational, but factors that contributed to their irrationality are not the same. Urban resident tend to be influenced mainly by money illusion, while rural residents tend to be mainly influenced by over-reaction to the price volatility, for the empirical results suggest that the regression coefficient between the Chinese urban residents real income per capita and the price increment is 108.41, which matches the expectation of money illusion hypothesis mentioned

Table 3. Estimation of irrational life cycle consumption function of urban and rural residents in China.

(a)

\begin{tabular}{ccccc}
\hline \multicolumn{5}{c}{ Estimation of irrational life cycle consumption function of Chinese urban residents } \\
\hline Real_Consume $(-1)$ & Real_Yield & Real_Yield (-1) & CPI - CPI (-1) & $R^{2}$ \\
$0.65^{\star * *}$ & $0.15^{\star * *}$ & & $108.41^{\star * *}$ & 99.8 \\
{$[0.006]$} & {$[0.037]$} & 0.20 & {$[7.82]$} & $(\%)$ \\
$(113.25)$ & $(4.11)$ & & $(13.87)$ & \\
\hline
\end{tabular}

(b)

\begin{tabular}{ccccc}
\hline \multicolumn{5}{c}{ Estimation of irrational life cycle consumption function of Chinese urban residents } \\
\hline Real_Consume (-1) & Real_Yield & Real_Yield (-1) & CPI - CPI (-1) & $R^{2}$ \\
$0.34^{* * *}$ & $0.27^{* * *}$ & & $-70.83^{* * *}$ & \\
{$[0.014]$} & {$[0.024]$} & 0.39 & {$[6.42]$} & 99.1 \\
$(24.43)$ & $(11.08)$ & & $(-11.03)$ & $(\%)$ \\
\hline
\end{tabular}

Note: ${ }^{* *}$ represents the statistical significance level of $1 \%,[]$ is the standard error, and () is the t-statistic value. Data source: China Statistical Yearbook. 
before. The regression coefficient in rural area is -70.83 , which corresponds with the expectation of the over-reaction hypothesis;

Third, according to the estimate result of irrational life-cycle consumption function, the model has a solid foundation in statistics and in economic theories. Therefore, the irrational life-cycle model of Chinese urban residents can estimated as: Real_Consume $=0.65 \times$ Real_Consume $(1)+0.15 \times$ Real_Yield +0.20 $\times$ Real_Yield $(-1)+108.41 \times($ CPI - CPI $(-1))$, and the irrational life-cycle model of Chinese rural residents: Real_Consume $=0.34 \times$ Real_Consume $(-1)+$ $0.27 \times$ Real_Yield $+0.39 \times$ Real_Yield $(-1)-70.83 \times($ CPI - CPI $(-1))$.

\section{Theoretical Analysis of Chinese Residents' Irrational Consumption Behaviors}

After the empirical research of applying Keynesian consumption function and life-cycle consumption function to macro-economic historical data in China, conclusion can be drawn that the consumption behaviors of Chinese residents are irrational. However, the reasons of their irrationality are different. Urban resident tend to be influenced mainly by money illusion, while rural residents tend to be mainly influenced by over-reaction to the price volatility. Explanations of the difference as given as following:

First, the "dual economic structure" between urban and rural areas in China is obvious, and the large difference in residents' income may lead to the phenomenon of "dual irrational consumption behavior". The so-called "dual economic structure" refers to the coexistence of developed modern industry and backward traditional agriculture. Priority to the development of reform and opening-up, China has established the urban modernization of industrial and commercial power paths, while rural still stays in the traditional self-sufficient smallholder economy era, under the background of the national level macro strategy, rapidly developed cities, rural development is relatively slow. The gap in development has led to significant differences in income levels between urban and rural residents in China. We can see from Figure 5 that there is not only a difference between the two, but also a gradually widening trend to some extent. For urban residents, first, the income level is relatively high, second, the commodity is abundant, and the consumption is convenient. When they know that the nominal income increases, they tend to spend too much. Suppose, for example, that a man earns 100,000 yuan a year, and his boss gives him a raise of 120,000 yuan next year, it also assumes that prices will rise by $20 \%$ next year, in practical terms, the prince has not changed anything, but the existence of a framing effect makes him pay more attention to income than price level, as nominal income rises, he will increase his spending budget. For rural residents, the long-term backward economic situation and the sense of self-sufficiency in small farmers, they tend to form conservative and prudent consumption habits and pay more attention to changes in commodity prices. When there is a significant fluctuation in commodity prices and there is no change in his actual situation, he will 


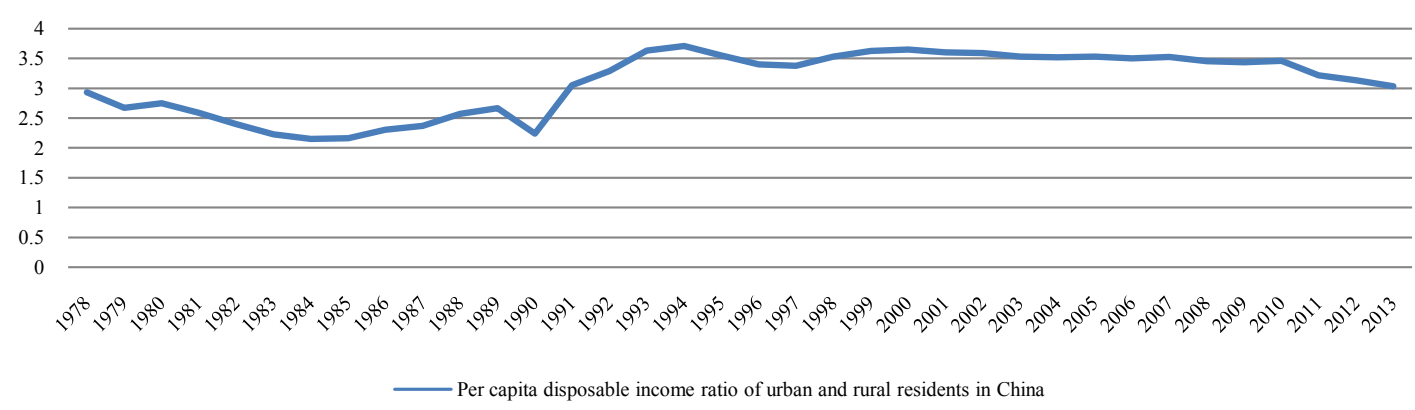

Figure 5. Per capita disposable income ratio of urban and rural residents in China. Data source: NBS, Collected by EPS DATA.

show a strong sensitivity. For example, when the price of a commodity rises sharply, the long-term consumption habits will allow them to suppress their inner desire for consumption, and they will choose irrational decisions that are less consumed or not consumed. In addition, the proportion of wage income in urban residents' income is larger and more stable, but the proportion of rural residents' income is small, and the agricultural production is greatly influenced by the climate and other factors. Therefore, the uncertainty of rural residents' income is greater, and the difference in income uncertainty between urban and rural residents may also be an important reason for the heterogeneity of urban and rural residents' irrational consumption behavior.

Second, the "dual education structure" of urban and rural areas in China is obvious, and the difference of resident culture education may lead to the phenomenon of "dual irrational consumption behavior". In China, the best educational resources are concentrated in the big and middle cities. The most famous primary and secondary schools and universities are almost rooted in the big cities. In addition, there are a series of modern libraries, science and technology museums, museums, gymnasiums and so on; citizens can enjoy colorful recreational activities. The modern communication facilities, such as cable TV, network broadband and mobile interconnection, cover all corners of the large and medium cities. Urban residents can easily receive modern cultural knowledge through various channels, while rural residents are very backward in educational resources and cultural facilities, basically in a semi-closed state. Although the Chinese government has been inclining to the rural areas in recent years, it still has a considerable gap from the input of the nine year compulsory education per capita of urban and rural residents. Because of the natural inferiority of rural children in basic education, and their parents far away from their native land to make a living in the city, the children's family education is seriously missing. Therefore, the opportunities for rural children to obtain higher education are not only small, but also less and less. In addition, the urban residents pay more attention to education and have a greater tilt in the investment of their children's human resources. Under the support of multiple realistic backgrounds, the comprehensive quality of urban residents and social knowledge are generally higher than those of rural residents. The concept of consumption is more open, 
they often inclined to open source rather than throttling, and the attitude towards consumption is relatively radical, while rural residents may be conservative and reserved because of limited social knowledge and educational level, thus showing excessive response to price fluctuations.

Third, China's urban and rural "dual social security" is obvious, and the difference in residents' risk resistance ability may lead to the phenomenon of "dual irrational consumption behavior". In the course of the reform and opening up, the vast rural areas not only supply the raw materials to the cities, but also deliver a large number of cheap labors, which constitute the most solid backbone of China's manufacture all over the world. They devoted their whole life to the modernization of the country, but most of them did not get the minimum living guarantee that the city should give, many migrant workers have only basic rural endowment insurance and medical insurance, most of which do not have housing provident fund benefits. Therefore, they lack a sense of security and are more afraid to consume at will. The differential treatment of urban and rural residents in social welfare, coupled with the household registration restrictions, makes the children of migrant workers in cities unable to receive free compulsory education in the city, or become left behind children, or spend high prices to read private schools, which undoubtedly brings heavy economic burden to the poor farmers' families. Therefore, under the driving force of no worries, urban residents have less psychological burden and are easy to develop the habit of consuming, when money income increases, it tends to be irrational and consume more; rural residents, on the other hand, have opposite personalities and habits. When commodity prices change greatly, they tend to make irrational decisions that consume less or even not.

Fourth, China's urban-rural "dual financial structure" is obvious, and the difference in income structure may lead to the phenomenon of "dual irrational consumption behavior". In twenty-first century, China's economic pattern gradually shifted from the era of industrial commercialism to the era of financial commercialism, the 10 year golden period of China's real estate market and the bull market in the stock market have all highlighted the new trend of China's economic development. However, participation in financial management is still dominated by urban residents. This is mainly based on three reasons: 1) the wealth of urban residents is much larger than that of rural residents, and they have more surplus funds than rural residents; 2) the awareness of investment and financial management of urban residents is stronger than that of rural residents. As the information channel of urban residents is complete and the economic knowledge is rich, they are easier to accept new things such as stocks, bonds, funds and other things; 3 ) there are many financial institutions in cities and towns, and there are many financial services, while rural residents seldom enjoy modern financial services, even though the state strongly advocates the construction of Inclusive Finance in rural areas, it is still far from the city. This kind of family financial management enables the urban residents to get a capital income besides obtaining the labor remuneration and they can advance credit 
consumption through consumer financial services of financial institutions. Therefore, the source of wealth for urban residents is relatively wide, which can also support their "capricious consumption" and make them irrational dependence on material goods. The income structure of rural residents is single and unstable, and they will not get paid through capital, so they will rationally curb their consumption behavior.

\section{Conclusions and Recommendations}

Theoretically, this paper established Keynesian consumption function and life cycle consumption function based on the irrationality of residents, through simple extension of adding price factors into the Keynesian consumption function and life cycle consumption function; in practice, the new model has been applied to calculate the irrational Keynesian consumption function and the irrational life cycle consumption function of Chinese urban residents from 1978 to 2009. The new model has also been applied to estimate the irrational Keynesian consumption function and the irrational life cycle consumption function of Chinese rural residents from 1985 to 2009. The three main conclusions are as follow:

First, the consumption behaviors of Chinese rural and urban residents are irrational. They are influenced by some irrational factors such as money illusion and over-reaction. The result of the empirical study shows that the real consumption level is influenced not only by real income, but also by the fluctuation of price level, which has a huge difference when the consumption function is based on the rational conditions. Thus, the consumption behaviors of Chinese rural and urban residents are irrational.

Second, Chinese urban residents have shown an obvious effect of money illusion, while Chinese rural residents have shown an over-reaction effect of price fluctuation. Although price fluctuation can influence the real consumption level of Chinese resident, the effects on rural areas and on cities are in opposite direction. The price level of urban residents has a positive relationship with the actual consumption level, whereas the price level of rural residents has a negative relationship with actual consumption level. Therefore, although they are both irrational, the performance of their irrational behaviors differs from each other.

Third, the reasons for the difference of their irrational behavior between Chinese rural and urban residents may be described in four aspects: 1) the income gap between Chinese rural residents and urban residents is big, and the dual economy characteristic is obvious in China; 2) the way of obtaining fortunes is not the same between Chinese rural and urban residents, and the difference of factors that contributed to their income is huge between them; 3) educational resources differ greatly between rural areas and cities, so does the comprehensive quality of consumers; 4) there is a big difference in public welfare and medical care for the aged between cities and rural areas.

Based on the three conclusions obtained above, based on the in-depth discussion of macro-economy and the reality of China's economic development, this article gives two suggestions as follows: 
First, the traditional economic research should be set up under the hypothesis of rational economic man, although many perfect economic mathematical models can be constructed, but some assumptions are contrary to the actual situation, which makes the model seem unable to explain the real economy. Therefore, it can be properly introduced into the rational model. The traditional model is supplemented and amended to achieve a more realistic simulation of the actual economic phenomenon.

Second, irrational behavioral factors, such as monetary illusion and overreaction, are at best a short-term psychological illusion of consumers. If the consumers tend to be rational in the long run, we can use newspapers, television and the Internet and other news media to report and publicize the irrational behavior of residents. By accepting more economic education about irrational behavior, consumers are aware of the difference between nominal and actual quantity, and their consumption behavior will gradually become rational.

\section{Funds}

Sponsored by 2017 National Social Science Foundation (Project Number: 17BGJ017); Sponsored by Y2016 Hunan Province Social Science Fund Decision-making Special Consultation Subject (Project Number: 16JCC006); Sponsored by Y2016 Hunan Province Social Science Planning Office (Project Number: 16YBA381); Sponsored by Y2014 Hunan Provincial Department of Education Reform Project (Project Number: 193).

\section{References}

[1] Wei, Y.G. and Su, X.L. (2005) Research on Psychological Effects in Consumer Psychological Accounts. Consumer Economy, No. 3, 70-72.

[2] Luo, W. and Wang, X. (2010) Literature Research on the Formation Factors of Irrational Consumer Behavior. China Market, No. 15, 105-106.

[3] Liu, J.G. and Liu, L.S. (2006) Irrational Consumption Behavior Theory and Empirical Analysis. Consumer Economy, No. 1, 85-88.

[4] Ren, Z. (2011) Analysis on Irrational Behaviors of Current Insurance Consumption of Chinese Residents. Consumer Economy, No. 4, 81-84.

[5] Du, W. (2014) Research on Irrational Real Estate Consumption Behavior. Enterprise Guide, No. 1, 76-77.

[6] Fang, Z.L. (2015) Changes in China's Household Consumption and Its Countermeasures in the Post-Crisis Era. Financial Studies, No. 1, 104-111.

[7] Ru, X.M. (2010) Deep Understanding of Farmers' Irrational Consumption Behavior. Business Research, No. 2, 53-55.

[8] Wang, L.F., Liu, Y. and Yin, Z. (2014) The Potential Influence and Countermeasure of Psychological Account on Irrational Consumption of College Students. Modern Education Science, No. 5, 65-69.

[9] Fisher (1928) Money Illusion. Adelphi, New York.

[10] Patinkin, D. (1965) Money, Interest and Prices. Adelphi, New York.

[11] Shafir, E., Diamond, P. and Tversky, A. (1997) Money Illusion. Quarterly Journal of 
Economics, 112, 341-374. https://doi.org/10.1162/003355397555208

[12] Tobin, J. (1972) Inflation and Unemployment. American Economic Review, 62, $1-18$.

[13] Akerlof, G.A. (2002) Behavioral Macroeconomics and Macroeconomic Behavior. American Economic Review, 92, 411-433. https://doi.org/10.1257/00028280260136192

[14] Modigliani, F. and Cohn, R.A. (1979) Inflation, Rational Valuation and the Market. Financial Analysts Journal, 35, 24-44. https://doi.org/10.2469/faj.v35.n2.24

[15] Campbell, J.Y. and Vuolteenaho, T. (2004) Inflation Illusion and Stock Prices. American Economic Review, 94, 110-116. https://doi.org/10.3386/w10263

[16] Brunnermeier, C.J. (2008) Money Illusion and Housing Frenzies. Review of Financial Studies, 362, 1012-1048. https://doi.org/10.1093/rfs/hhm043

[17] Cohen, R.B., Polk, C. and Vuolteenaho, T. (2005) Money Illusion in the Stock Market: The Modigliani-Cohn Hypothesis. Quarterly Journal of Economics, 120, 639-668.

[18] Liu, R. (2009) Inflation and Stock Price Volatility in China: Explanation Based on the Currency Illusion Hypothesis. Research on Quantitative Economy, Technology and Economy, No. 5, 65-69.

[19] Chen, G., Zhang, Y. and Wang, J. (2009) Analysis on Factors Influencing Resale Options, Inflation Illusion and Chinese Stock Market Bubble. Economic Research, No. 5, 106-114.

[20] Zhang, Z. and Zhu, W. (2010) Inflation Illusion, Expectation Deviation and Stock Market Valuation. Financial Research, No. 5, 75-82.

[21] Tyran (2007) Money Illusion and the Market. Science, 317, 1042-1043. https://doi.org/10.1126/science.1143917

[22] Bakshi (2009) Money Illusion and Economic Education. Review of Financial Studies, 36, 112-119.

[23] De Bondt, T. (1985) Does the Stock Market Overreact. Journal of Finance, 40, 102-109. https://doi.org/10.1111/j.1540-6261.1985.tb05004.x

[24] Fama (1981) Stock Returns, Real Activity, Inflation and Money. American Economic Review, 71, 545-565.

[25] Zhang, R., Zhu, P. and Wang, H. (1998) Empirical Test of Overreaction of Shanghai Securities Market. Economic Research, No. 5, 58-63.

[26] Wang, L., Kong, D. and Chen, W. (2011) Herd Behavior of Securities Investment Funds and Overreaction of Stock Market. Southern Economy, No. 3, 69-77.

[27] Lu, G. (2012) The Excessive Response of Stock Price to Accounting Surplus and Capital Allocation Efficiency. Nankai Management Review, No. 6, 25-33.

[28] Gao, H. and Zhang, M. (2015) Empirical Study on the Overreaction of a-Share Market in Heavy Polluting Industries. Accounting Research, No. 2, 64-68.

[29] Jiang, S. and Wu, C. (2007) The Effectiveness of China's Futures Market: The Perspective of Overreaction and Correlation between Domestic and Foreign Markets. Financial Research, No. 2, 49-62.

[30] Zou, X. (2003) Empirical Analysis on the Overreaction of China's Securities Market Returns. Economic Science, No. 4, 32-40.

[31] Cai, L. and Zhu, H. (2006) Empirical Research on the Overreaction of China's Securities Market. Comparison of Economic and Social Systems, No. 2, 62-65. 
[32] Gong, G. and Lin, Y. (2007) Overreaction: The Explanation of China's Economic "Shrinking". Economic Research, No. 4, 53-66. 